\title{
REGIONAL MODELS OF URBANIZATION AND NATIONAL IDENTITY DEVELOPMENT (CASE STUDY OF BELARUS)
}

\author{
Siarhei Danskikh \\ Yanka Kupala State University of Grodno, \\ Faculty of History and Culture, \\ Ozheshko str. 22, 230023 Grodno, Republic of Belarus \\ E-mail: sdanskikh@grsu.by
}

\begin{abstract}
The article discusses the influence of the process of urbanization on the Belarusian nationality. Due to some historical conditions the Western cities-communes have not formed in Belarus. At the beginning of the New Ages the Belarusian city has had Magdeburgian law and the trading relations, it has been the centre of the political life, the residence of the State officials and the provinces. Through the social-economical backwardness of the Russian empire the peasants of Belarus could not move into the towns from the country. The towns and the cities in Belarus were not Belarusian but Jewish and Polish ones. Due to the World War II there have emerged the Polish Holocaust, repatriation and the Soviet industrialization which have made some auspicious conditions for the overtaking modernization in Belarus. During only one generation the peasant Belarusian nation has become the urban one. Such overtaking process of the urbanization has been preventing the formation of the standards and the traditions of the Belarusian city. The basis of the social and cultural life of Belarusians has been forming the traditions of the Soviet culture. That is why we can come to the conclusion that the overtaking modernization is closely related to the radical changes of the national identity. The more overtaking is modernization of the cities and the whole State, the more dangerous is the deprivation of the national peculiarity. The nation whose spiritual life is not utterly formed can hardly successfully adapt itself to the social and economical changes, which are determined by the overtaking modernization. These alterations do absolutely not correspond to its spiritual way of life.
\end{abstract}

Keywords: Republic of Belarus, creolization, ethnic-confessional structure, overtaking nation modernization, national identity, russification, sovietization, urbanization.

DOI: $10.3846 / 2029-0187.2008 .1 .88-98$

Countries, which are "overtaking modernization" in the anthropological and cultural dimensions, make the possibility to face the problems, which are unfamiliar to progressive countries of the Modern civilization. The processes of industrialization, commercialization, individualization and urbanization are universal for modernization, but in the former countries they are affected by a number of external reasons and take two different forms: 
they are involved in the orbit of modernization of more successfully "developed" and "civilized" countries;

the political and intellectual elites of these countries desire to "overtake and surpass” progressive countries voluntarily.

In both cases the "overtaking modernization" turns out to be hostile and misunderstood by the countries at the periphery of the present-day capitalist economic world and goes on at a rapid pace. Within one generation there occurs a sharp change of traditional and contemporary ethoses and the city is the most important socio-cultural sphere of their transformation, assimilation and interaction. It is the city, where people of the traditional society face new "structures and practices of the present day", even though they are not immediately involved in them.

The aim of this article is to show anthropological peculiarities and consequences of the urbanization on the frontier of the European periphery of the Western economic world and Russian empire world based on the case study of Belarus. Following the historical works of Emmanuel Wallerstein, Fernand Brodel and Jenö Szücs the European periphery of the Western economic world includes the territory between the Elba in the west, the Baltic Sea in the north, the borders of the Russian Empire in the east and the Turkish Empire in the south. Historically the bases of this area were Polish-Lithuanian Commonwealth and the "scrappy” Habsburg Empire. In the context of the present-day research it is the territory of Central Eastern Europe: Hungary, Czech Republic, Slovak Republic, and Poland. The borders of this area used to be mobile and in the Early New Time they included Croatia, Lithuania, Belarus and the greatest part of the Ukraine and Romania. Thus, the frontier of the European periphery of the Western economic world and Russian empire world covers the territory of Central Eastern Europe, which went into political, economic and socio-cultural "orbit” of the Russian empire world after 1800. But it was not until the middle of the XX century, when their final social, political and economic integration with the new "civilization” occurred (Szücs 1995; Kłoczowski 2000). As long as the Ukrainian identity has both western and eastern directions and the Lithuanian identity belongs to both Central Eastern and Baltic regions, Belarus can be considered as "the purest" example of the frontier of the European periphery of the Western economic world and Russian empire world. And since the article deals with national identities, i.e. ethnic social patterns of the New Time, the development and socio-cultural role of the cities in Central Eastern Europe are studied beginning from the XVI-XVII centuries.

It is not by accident that the process of finding national identity is chosen out of numerous socio-cultural transformations which accompany the process of modernization. The majority of Central Eastern countries consider national revival and national liberation struggle as the final goal of modernization. The national was interpreted as the highest value of the past and future generations. The Belarusian pattern seems a little uncommon against this background especially for neighboring countries.

In spite of old scientific debates about the correlation of modernization and industrialization processes and national identity, it is obvious that they are closely interrelated. 
According to Miroslav Hroch, modernization as a process of changing from agrarian feudal society to the present-day industrial capitalist society included three dimensions:

constitutional reforms, an adoption of the system of modern civil and political rights, including the equality of citizens;

industrialization which meant not only industrial revolution but also radical changes in agriculture, transportation, communication as well as rationalization of administrative system (unification, bureaucratization);

the rise of horizontal and vertical social mobility including intensification of social communication (Hroch 2003: 139).

According to Hroch, the process of urbanization which had changed the social structure and settling of the population rather than industrialization itself played a decisive role for the processes of national self-identification. Industrialization could precede the process of national revival and the development of nations as well as could start within national countries. Urbanization has always been a sort of catalyst of "national integrative” processes. On the basis of a case study of Czech Republic, Hungary, Finland, Estonia and Latvia Hroch showed the positive role of the city in the development of present-day nations.

As Bruce Anderson and Ernest Gellner stated, national identity is in the first instance social group identity which is associated with a large amount of people. National self-identification manifests itself in acquiring a definite socio-cultural pattern that makes communication between members of a nation effective. Presumably, the city does not only symbolize the success of the modern industrial society but also favors national identity of a new kind: homogeneous, democratic and mobile. Peasants of the agrarian society have their own ethnic identity in which the local and the common excel the national in its significance.

The beginning of the New Time, the development of the Western capitalist economic world, first originated in the Netherlands, and the colonial expansion of the West determined the conversion of Central Eastern Europe into the periphery of the countries that pioneered modernization. Szücs admitted that feudal latifundia with serf peasants in Eastern Europe became typical partners of Western Europe within the world division of labor (Szücs 1995: 75-76). It resulted in "secondary feudalism”, stagnation and crisis of the Eastern European cities. Some seaports in the mouth of the biggest rivers became the most "developed" and the richest cities of the region, for instance, Danzig (Gdansk) on the Visla, Riga on the Daugava and partly Memel (Klaipeda) on the Nemunas. And that was due to their location on the East-West trade routes. Raw agricultural materials were delivered to these cities and then were conveyed by the Baltic Sea to industrial centers of the West. Those cities came into being in the Middle Ages as a result of economic expansion of Hansa which was a trade political union of North German cities. They were typical German burgher cities that did not even attempt to play any political or industrial-economic role in the region. In fact, Danzig and Riga being occupied with Baltic international trade were the only "real" cities of the region. They were communes of citizens who were not differentiated socially but economically. 
Civilizing influence of German seaports resulted in the spread of the Magdeburg Right on the territory of the Grand Duchy of Lithuania. The Magdeburg Right is a municipal legal code that confirmed the rights and liberties of city-dwellers including the right for self-government. The Magdeburg Right was granted to a number of Belarusian cities by Polish kings and Grand Dukes of Lithuania: Brest (1390), Grodno (1391), Slutsk (1441), Polotsk (1498), Minsk( 1499), Volkovysk (1503), Novogrudok (1511), Mogilev and Rechtsa (1561), Lyda (1587). Royal “privileges” had been granted to Belarusian cities and boroughs up to the middle of the $18^{\text {th }}$ century but they lost their "social” significance. These privileges mainly presupposed the right for conducting weekly markets and periodic (once or twice a year) fairs. But on the whole it was not easy to inculcate the Magdeburg Right upon Belarusian cities because they were disrupted on ethnic confessional basis into three social groups: Catholics, Orthodoxes and Jesuits.

The second group of the frontier cities at the periphery of the Western economic world and Russian empire world was represented by Vilnius/Vilno (the capital of the Grand Duchy of Lithuania), Grodno (the city where "Seyms" - gentry parliaments of Polish-Lithuanian Commonwealth were held) and partly Novogrudok (the first capital of historical Lithuania). The population of those cities was not high. At the end of the XVIII century Vilnius numbered about 15000 people, Grodno - 6000 people and even less in Novogrudok. Serving the democracy of the Polish/Lithuanian gentry those cities did not play any significant economic role but were famed as religious (Catholic) and educative centers. If we do not give much attention to Jewish blocks with population ranging between $40-60 \%$ of the total number, Belarusian "political” cities of the Early New Time were typical Polish/Lithuanian gentry Catholic cities.

Those cities seemed unusual for Western European travelers because they lacked regular planning. Luxurious abbeys, churches in baroque, magnates’ palaces alternated with miserable wooden hovels. This description of Grodno was made by the English traveller William Coxe in 1784 (Вульф 2003: 68). It should be noted that every third Polish/Lithuanian Seym was held in Grodno and the city was of great political importance. As long as "juridiki” (lands which were under the jurisdiction of the church and magnates and did not subordinate to municipal magistracy) constituted a considerable number of the cities, there was nothing surprising in the lack of accurate planning and alternation of wealth and poverty. Such a contrast only proved how scantily the Magdeburg Right influenced the real city life.

The population of "political” gentry cities was not invariable. It increased several times during the Seym and some other political activity and declined as that activity lulled. For instance, Vilnius was the third city of the Russian Empire in the number of population in 1811. It numbered 56000 people whereas Riga was only the eighth with the population of 32000 people. And that was the result of political activity on the eve of the war in 1812 and Mikhail Speransky and Michal Oginsky's plans to restore the Grand Duchy of Lithuanian. But 100 years later economics put everything in the proper place making Riga the third city in the Russian Empire with the population of 558000 people while Vilnius was not even in the top ten. 
Residential cities of Polish/Lithuanian magnates on the territory of Belarus were a noticeable phenomenon: Radzivills (Radvilos) in Nesvizh, Sapeges (Sapiegos) in Ruzhany, Oginskies (Oginskiai) in Slonim, Tyshkevichius (Tiškevičiai) in Svisloch. Those cities symbolized the grandeur of the Polish/Lithuanian aristocracy and had all the attributes of Western European cities including the right for local self-government and large groups of foreign (mainly German) craftsmen occupied in luxury manufacturing.

That pattern was universal and inevitable for the frontier of the European periphery of the Western economic world and Russian empire world. It can be vividly seen in the fact that the Russian aristocracy reproduced an analogous type of "representative" residential cities on the East of Belarus after Polish-Lithuanian Commonwealth had been divided. The examples are Gomel of Prince Pashkevich and Shklov of General Zorich.

Boroughs made up the forth urbanization level. They cornered and resold local raw agricultural materials. The number of the population of a borough ranged between 150 and 500 people. About $80 \%$ of the population was the Jews, whose small-scale retail trade and handicrafts met the requirements of the local gentry and peasantry in goods and facilities. The socio-cultural life in boroughs in the Early New Time was a typical example of living in diaspora with vividly pronounced cultural segregation. It was visually manifested in the "universal" language of the Jews living in Belarusian boroughs - Yiddish which was used as a spoken language. Despite Yiddish borrowed some Slavic vocabulary, mainly German dialects formed the bases of it. There were 272 boroughs on the territory of Belarus at the beginning of the XVII century. That number reached 418 by the year 1863. At the beginning of the XX century there were 44 cities and 322 boroughs, which accordingly was $0.1-0.6 \%$ of the total number of settlements (Соркіна 2001: 21-24).

Thus, in XVI-XVII centuries Belarusian cities differed greatly from the "model" Western European cities in the level of development and economic functions. Belarusian cities occasionally attended to transit trade of the West and East (Polotsk, Mogilev, Brest) and more often accumulated and conveyed raw agricultural materials to Western European markets, confirming the peripheral status of Central Eastern Europe in that way.

The question of the ethnic confessional structure of the population in Belarusian cities has not been studied much. Probably, the events in the middle of the XVII century, i.e. the wars between Polish-Lithuanian Commonwealth and Russia, Sweden and the rebelled Ukrainian Cossacks had negative consequences there. The wars resulted in huge losses in the urban population and, first of all, in the lower middle class who were mainly Christians of Eastern rite. Jewish merchants and craftsmen who had escaped Cossack massacres in the Ukraine and settled in Belarus partly compensated those loses. It increased the part of the Jewish population. The second group of city-dwellers was Polish and German craftsmen who were invited by the royal administration and magnates. According to revision findings in 1795, only 19786 people out of 295030 of the male population of Lithuanian Grodno Province could be considered as city-dwellers: 13097 Jews and Karaites, 5681 local craftsmen and the lower middle class, 1008 foreign craftsmen. In fact, in 1800 the urban population made up only $6.7 \%$ of the total 
population of Lithuanian Grodno Province. 66.2\% were the Jews, 5.1\% were foreigners and only $28.7 \%$ were the local population that was not necessarily represented by the Belarusians in Western Belarus (НИАБ). In such situation there was no room in the city for a Belarusian peasant even in case of assimilation.

As a result, Belarus was not involved in the process of urbanization up to the middle of the XIX century. The Belarusian city was not a national city in the present-day meaning of this word. It looked rather like Eastern cities with their class and caste structures which came to their logical ethnic end in Belarus: the Polish/Lithuanian gentry city and the Jewish trade handicraft borough. A Belarusian could only be a peasant for whom there was no room in the city. It is not surprising that only $13.5 \%$ of the Belarusian population lived in cities at the end of the XIX century. In Europe this number was 29\% and in Central Eastern Europe, including Austria - 18\%. Moreover, only 2.3\% of ethnic Belarusians lived in cities where they made up $17 \%$ of the population. $97.7 \%$ of Belarusians lived in the country-side and made up $88.3 \%$ of all peasant population of the country (Radzik 2000: 140; Хобсбаум 1999: 489; Вайтовіча, Данілава 2000: 243).

At the end of the XX century Gellner (Геллнер 1991) admitted that the process of national revival is not historically inevitable. It starts only when the peasantry - "ruritans" - is awoken by modernization and has no possibilities for equal integration into "historical nations" with "complete social structure”, into the society of “Megalomania” (Геллнер 1991: 154-159). Gellner introduced a metaphorical term - "blue skin" - a factor which prevents the ruritans from integrating and assimilating into the society of "Megalomania” in spite of all efforts and identification forms. Various bans and restrictions imposed by German citizens, trying to prevent Latvian and Estonian urban population from moving to the city, can serve as a historical example of that pattern. Thus, ethnic origin was "blue skin" in that case. Religion was "blue skin” in Polish-Lithuanian Commonwealth, which made Belarusian and Ukrainian integration impossible.

The situation changed radically when the Belarusian lands entered the Russian Empire. The social economic backwardness of the Russian Empire brought into a deadlock. On the one hand, the Russian political and intellectual elite declared a community or even a unity of the Russian (Eastern Slavic, Orthodox) population of the Empire: the Russians, the Ukrainians and the Belarusians. The Ukrainian, the Belarusians (in some Slavophil works, e. g. by Aksakov) and the Lithuanians were considered as ethnographic branches of the united Russian nation. On the other hand, being a typical class state of the "ancient regime", the Russian Empire could not ensure the equality for its Orthodox peasant citizens from Belarus and the Ukraine. But there was always room for the Polish/Lithuanian aristocracy at court, especially in the times of Alexander I. The Jewish pale enabled Russian emperors to detain and concentrate the surplus Jewish population on the territory of Belarus, which closed Belarusian cities for Belarusian peasants even after the emancipation of serfs in 1861. In fact, national equality with the "title ethnos" of the Russian Empire was declared to the Belarusians in the XIX century but no civil rights and social economic prospects were offered. Probably, it caused 
the following peculiarities of the Belarusian national movement at the beginning of the XX century:

- being deprived of urban centre and social political and intellectual elites it was weak and did not turn into a mass movement;

- Belarusians were inclined to support social Bolshevist slogans but not national programs of Belarusian parties. And that was due to the fact that according to some stereotypes of the second half of the XX century the task of national liberation had already been fulfilled by Russian tsars.

Thus, the type of "the national city", that could have integrated the surrounding territory into the world economic system as well as organized the local production, could have formed national elites and social groups typical of the modern society, was not formed in Belarus. The development of the national self-awareness was influenced by the image of exceptionally peasant nation. In contemporary Belarusian national literature there is no city that is described as "one's own space” or "ideal space" that man is longing for. It appears episodically on literary pages and mainly while describing a visit to a fair/market or an official institution. So, the key symbol of the modern society turns out to be misunderstood and unclaimed if not alien to the Belarusians.

The situation changes radically in the first half of the XX century. In 1939 the urban population of Belarus reached $20.8 \%$ and in $1959-30.8 \%$. Besides, it was the time when the Belarusian city proper started to be formed. The Great Patriotic War did not only destroy the majority of Belarusian cities but also changed their ethnic social structure. The greatest part of the Jews felt a victim to holocaust, unleashed by the fascists and the Poles were sent off to the western (post German) regions of Poland as a result of the post-war repatriation. The new "Belarusian Soviet” cities were primarily the centers of railway intersection "free from any historical traditions" and were given an administrative status of regional centers by the Soviet Government: Minsk, Gomel, Brest, Baranovichi, Vileika (the two latter did not preserve their status after the Second World War). A rapid growth of industry which began in the 50s demanded considerable manpower. It was provided by collectivization which had ended by that time. The Belarusians made up 61.6\% of the urban population of BSSR in 1959 and $73.2 \%$ in 1989. Close links with the country-side were an important peculiarity of Belarusian city-dwellers, because only 61.65 of the Belarusian people lived in cities against 86.8\% of the Russians and 99\% of the Jews (Беларусы 2001: 288-289).

As a result, a peculiar type of a Belarusian as “a temporary city-dweller” formed. They spent their weekend and holidays in the country busy with agricultural work. That phenomenon was widely spread among the citizens who were registered in different kinds of hostels and "malosemeykas". They numbered around 600 thousand people (about $6 \%$ of the country population) at the end of the XX century. A summer-cottage (“dacha”) became an obligatory attribute of the Belarusian city-dweller, which of course was not related to economic problems in "model” BSSR that was ignorant of food deficiency. Socio-cultural standards and modern tendencies of modernization (including rock music) underwent peculiar "pastoralization” in Belarusian cities when they entered the urban environment. The examples are the Belarusian bands of the70s 
such as "Pesnyary”, "Syabry”, “Charovnitsy” and "Verasy” with their "folk” aesthetics, though in a lesser degree.

The majority of the Belarusians living in cities were city-dwellers in the first generation. The inland migration of the rural population into cities made up about 94000 people a year from 1970 to 1978 and 76000 people a year from 1979 to 1989. Those were impressive figures for a republic with 10 -million populations. Nevertheless, Belarusian cities were not Belarusian in the true sense of this word. Their structure and present-day practices were determined by the aims of the Soviet Government and all-union plans for industrial development. The city elites were represented by Party and Soviet workers, directors of industrial enterprises and partly by intelligentsia with higher education. All those social groups were the carriers of the Soviet variant of the Russian culture that became normal for a Belarusian and primarily for a Belarusian city-dweller.

While comparing Belarusian industrialization with the similar processes in Central Eastern European countries it should be noted that the Soviet Government played a decisive role in that process. It threw a lot of factors which other countries had never even dreamt of on the "history scale" of the Belarusian city. Those are large-scale industry, numerous Soviet Party machinery, a powerful army (BSSR was made as an informal "tank republic" by the Belarusian military district). As a result of the Second World War the majority of Belarusian cities were "tabula rasa" in a physical as well as anthropological dimensions. In fact, since the middle of the XX century the Soviet Government did not have any competitors and alternative sociocultural patterns while forming the Belarusian city. The Belarusians lost their own urban traditions in the middle of the $17^{\text {th }}$ century. The Polish and Jewish urban population quit the historical stage. And their architecture and cultural landscapes full of definite symbols were almost completely destroyed by the war. Belarusian cities were not often restored but were built anew. The centre of modern Minsk (Independence Avenue, the former Francisk Skorina Avenue) that was built from scratches after the war is a classical example of that. It is also a classical example of "Stalin Empire-style" for lots of historians of architecture.

Thus, the processes of urbanization appeared to be directly proportional to the processes of russification. According to the findings of the general census of the population in 1979, all urban population of BSSR spoke Russian fluently and only a half spoke Belarusian. In the country-side the situation was opposite. It may be said that as long as the Belarusian culture lacked "the urban being standard” rapid urbanization was called into being by "overtaking Soviet modernization" and left no time for the Belarusians to cultivate national traditions of urban life. The Russian culture in its Soviet variant was normal for a Belarusian city-dweller who knew that in order to have higher education, a career, an adequate cultural level and social status one should correspond to the Russian Soviet cultural standards. As a result, it changed the correlation between the Russian and Belarusian languages in mass media, education, legislation, office work, science and culture. In 1932 nearly 1300 Belarusian periodicals were published in Belarusian and only 25 in Russian. In 1987 those figures were opposite - there were 375 periodicals in Belarusian and 2507 in Russian. By the year 1987 all pre-school institutions in Belarusian cities educated in Russian. Only 23\% of pupils went to schools educating in Belarusian. But in Minsk and other regional and district centers there were no Belarusian schools (Типология двуязычия и многоязычия в Беларуси 1999: 121, 139-141). Among 
the elite layers of the population only creative intelligentsia and humanitarian scientists were the carriers of the Belarusian language and culture.

The 90s signified a new period in the development of the Belarusian urbanism - the emergence of megapolises or a megapolis to be precise (the size of the country would not allow to have more). When Minsk became the capital of Belarus, it kept increasing its population at a rapid pace. Its population numbered 256 thousand people in 1940, 509 thousand in 1959, 917 thousand in 1970, 1276 thousand in 1979, 1612 thousand in 1989 and 1677 thousand in 1999. In 2005 the population of Minsk reached 1800 thousand people, which made the status of the capital in the country with less than ten million people population exceptional. Moreover, Minsk comes practically to Warsaw in the number of population, while the population of Poland is only four times bigger than the population of Belarus (Типология двуязычия и многоязычия в Беларуси 1999: 178; Население Республики Беларусь 2000: 27). Minsk city council (1 680.5 thousand people) is the largest administrative unit of the republic and exceeds other regions in the number of population. Taking into account modern demographic tendencies Belarus is supposed to have the population of about 6-6.5 million people with 2-2.5 million capital-dwellers by 2050. In fact, the country may turn into "the capital suburbs". According to the findings of the general census of the population in 1999, more than a half of the republic population lived in 24 biggest Belarusian cities (with the population of more than 50 thousand people).

The population of Minsk is getting bigger at the expense of young people, businesslike people and intellectual elite. (Those who have defended a thesis for a Doctor's degree or have got a degree in a prestigious social economic science are likely to settle in Minsk). The sociological survey of the Yanka Kupala University of Grodno applicants in 2004-2005 showed that most school- and lyceum-leavers aim at getting into Minsk universities and settling in Minsk later on. They point at the prestige of Minsk, greater possibilities for getting a job, varied cultural life as the main reasons for their choice while material factors are not important for them.

The size of Belarus allows to get to Minsk by car within 3-4 hours from any regional centre and that is why the capital takes "the national territory under its control", which is easier to do than in Russia. The capital mass media cover the whole territory of Belarus. A peculiar "secondary” peripheral self-awareness is being formed in Belarusian regional centre. The market also reacts to this new situation. Top-quality goods, including food stuffs, have the word "Minsk" in their name.

Some Belarusian researchers consider self-awareness of the Belarusian city-dweller through the notion of "creolization". Thus, it can be assumed that the processes of socio-cultural assimilation can succeed only in case they are attended by the processes of socio-cultural transformation. In the given case they are associated with modernization, with urbanization being its broadest social context. As a result of the Belarusian urbanization according to the Russian-Soviet pattern the Belarusian urban population has become the carrier of the Russian culture. The Referendum results in 1996 confirmed that and also made Russian the state language in Belarus de-jure and the predominant language de-facto. But Belarus is an independent national state and could not 
allow the urban population to associate itself with Russia in full measure. Complete identification with a parent state is impossible for "Creoles" who have taken root into some "other space”. National identification proper is either vague or "doubled" in this case (e. g. Latin-American "Spanish spanishness" and analogous "Belarusian russianness”) (Абушенко 2004: 124-156).

It can be assumed that the "creolization” of the Belarusian urban population was a success not only due to decisive measures of the Soviet Government. Up to the beginning of XX century Belarusian peasants identified themselves through the "local" but not "national" identification by force of some historical peculiarities, i.e. the lack of universally recognized national urban cities. In terms of "creolization” thinking was in harmony with certain archetypes of the consciousness of the Belarusians who were city-dwellers in the first-second generation. But the local color either taken by itself for a "local peasant" or relative to the Russian cultural world for a "creolized" city-dweller was in the first place. Belarusian national culture that was linked either to the Soviet system of official culture or to some oppositional "national conscious" trends did not appear to be ready for a "creolic" challenge of the modern Belarusian urban culture. The official Belarusian culture with its Belarusian language and three main topics: the peasantry, the war and Chernobyl became unclaimed by the Belarusian "creolized" city-dwellers who were drawn towards living in a megapolis.

\section{Conclusions}

The "national conscious” Belarusian culture was refined that it was familiar with postmodernistic aesthetics and filled with medieval stylizations but was incomprehensible to the majority of Belarusian city-dwellers in the first and the second generations and was locked within one of the youth subcultures.

And only the Belarusian Government was sensitive to the sentiments of citizens and responded to the needs of "creolized" citizens, having created a national variant of the Russian pop-culture with its three pillars: the television (ORT/ONT), FM stations and pop music.

Thus, “overtaking modernization” is inevitably linked to radical changes in people’s identification. The faster and more successful the tempos of "overtaking modernization” are, the better chance of losing the national identity and assimilating or creolizing people is; even though these people do not have time to work out spiritual national forms corresponding to swift social economic changes.

\section{References}

Hroch, M. 2003. Małe narody Europy. Wrocław: Zakład Narodowy imenia Ossolińskich - Wydawnictwo. Kłoczowski, J. (Ed.) 2000. Historia Europy Środkowo-Wschodniej, t. 1-2. Lublin: Instytut Europy Środkowo-Wschodniej.

Radzik, R. 2000. Między zbiorowościq etniczna a wspólnotq narodowq. Białorusini na tle przemian narodowych w Europie Środkowo-Wschodniej XIX stulecia. Lublin: Wydawnictwo UMCS.

Szücs, J. 1995. Trzy Europy. Lublin: Instytut Europy Środkowo-Wschodniej. 
Абушенко, В. 2004. «Креольство как ино-модерность Восточной Европы (возможные стратегии исследования)», в кн. Перекрёстки 1-2: 124-156.

Бандарчыка, В. К. (Еd.) 2001. Беларусы: Вытокі і этнічнае развіциё, t. 4. Мінск: Беларуская навука.

Вайтовіча, А. П.; Данілава, А. М. (Еd.) 2000. Беларусь на мяжы тысячагоддзяў. Мінск: Беларуская Энцыклапедыя.

Вульф, Л. 2003. Изобретая Восточную Европу. Карта иивилизации в сознании эпохи Просвещения. Москва: Новое литературное обозрение.

Геллнер, Э. 1991. Нации и национализм. Москва: Прогресс.

Население Республики Беларусь: Статистический сборник. 2000. Минск: Министерство статистики и анализа Республики Беларусь.

Соркіна, І. В. 2001. Мястэчкі Беларусі. Гродна: ГрДУ ім. Янкі Купалы.

Типология двуязычия и многоязычия в Беларуси. 1999. Мінск: Беларуская навука.

Хобсбаум, Э. 1999. Век Империи. 1875 - 1914. Ростов на Дону: Феникс.

\title{
REGIONINIAI URBANIZACIJOS IR TAUTINIO TAPATUMO PLĖTROS MODELIAI (BALTARUSIJOS ATVEJIS)
}

\author{
Siarhei Danskikh
}

Santrauka

Šiame straipsnyje apmąstoma urbanizacijos proceso įtaka baltarusių tautiškumui. Dèl tam tikrų istorinių sąlygų Baltarusijoje nesusiformavo vakarietiško pobūdžio miestai-komunos. Naujųjų laikų pradžioje baltarusiškas miestas turèjo Magdeburgo teises ir prekybinius santykius, buvo politinio gyvenimo centras su valdininkijos rezidencija ir provincijomis. Dèl Rusijos imperijos socialinio-ekonominio atsilikimo Baltarusijos valstiečiai negalejo iš kaimų persikelti gyventi i miestus. Pastarieji iki pat XX amžiaus pradžios buvo ne baltarusiški, bet žydiški arba lenkiški. Antrasis pasaulinis karas lėmè lenkų holokaustą, repatriaciją ir tarybinę industrializaciją, kuri sudare palankias sąlygas sparčiai Baltarusijos urbanizacijai. Būtent dèl šio proceso labiausiai nukentėjo valstiečiai. Tereikèjo vienos kartos, kad valstietiška baltarusių tauta taptų miestiška. Toks spartus urbanizacijos procesas neleido susiformuoti baltarusiškojo miesto gyvenimui būdingoms normoms ir tradicijoms. Baltarusių socialinio ir kultūrinio gyvenimo pagrindą sudarè rusų sovietinès kultūros tradicijos. Taigi sparti modernizacija glaudžiai susijusi su radikaliomis tautinio tapatumo permainomis. Kuo sparčiau modernizuojami miestai ir visa valstybė, tuo didesnis pavojus prarasti tautinį savitumą. Tauta, kurios dvasinis gyvenimas dar nėra visiškai susiformavęs, vargu ar gali sėkmingai adaptuotis prie itin sparčios modernizacijos nulemtu socialinių ir ekonominių pokyčiu, kurie visiškai neatitinka jos dvasinio gyvenimo būdo.

Reikšminiai žodžiai: Baltarusija, sparčioji modernizacija, urbanizacija, tautinis tapatumas, etninè-konfesinè struktūra, rusifikacija, sovietizacija, kreolizacija. 